\title{
Prevalence of Pulmonary Tuberculosis in Jutpani VDC, Chitwan, Nepal
}

\author{
Kapil Amgain and Mahendra Maharjan \\ Central Department of Zoology, Tribhuvan University, Kirtipur, Kathmandu.
}

For correspondence: mmaharjan@cdztu.edu.np

\begin{abstract}
Tuberculosis (TB) is one of the major public health problems in the developing countries like Nepal. The present study was carried out in Jutpani VDC of Chitwan Nepal from July to December 2012 with the objective to determine the situation of Tuberculosis in Jutpani VDC, Chitwan. During the study period, a total of 600 sputum samples from $200 \mathrm{~TB}$ suspected patients were collected and examined in the Laboratory of Jutpani Primary Health Center (PHC). Diagnosis was made after staining the sputum smear by Z-N staining method and examined under light microscope. Out of 200 TB suspected patients, 18(9\%) were found to be AFB positive. Among patients diagnosed as having pulmonary Tuberculosis (PTB), males $(55.56 \%)$ were found to be infected more than females $(44.44 \%)$ which was found to be statistically insignificant $\left(\chi^{2}\right.$ cal. $\left.=0.4524, \mathrm{P}<0.01\right)$. Highest prevalence of TB infection $(36.89 \%)$ was found to be in the age group of 30-40 years. A questionnaire survey of 57 Pulmonary Tuberculosis (PTB) patients was done to assess their knowledge, attitude and preventive practices for TB. Out of 57 PTB patients interviewed, majority of the patients had positive attitude but the knowledge regarding cause, transmission, prevention of the tuberculosis was not adequate.
\end{abstract}

Key words: AFB, Mycobacterium tuberculosis, PHC, PTB, Z-N stain

\section{Introduction}

Tuberculosis (TB) is the world's most serious public health problem particularly in developing and under developing countries. It is a disease of great antiquity and contributing to more morbidity and mortality than any other bacterial infection (Grange et al. 1998). It causes ill-health among millions of people each year and ranks as the second leading cause of death from an infectious disease worldwide, after the human immunodeficiency virus (HIV) (WHO 2012a). Approximately one-third of the world's population is infected from TB (Miller and Schieffelbein 1998). There were almost 9 million new cases and 1.4 million TB deaths (9,90,000 among HIV-negative people and 4,30,000 HIV-associated TB deaths) in 2011 (WHO 2012b). So, TB remains one of the deadliest threats to public health.

TB is an infectious disease caused by the bacillus Mycobacterium tuberculosis that spreads to others via aerosol route. TB typically affects the lungs (pulmonary TB) but can affect other sites as well (extrapulmonary TB) (Kumar et al. 2007). It is estimated that 6 out of 10 adults in Nepal are infected with TB and 80,000 Nepalese people have active TB disease and every year, 40,000 people develop active TB, of whom 20,000 have infectious pulmonary disease (DoHS 2004/2005).

Nepalese Journal of Zoology | Online Volume 3 Issue 1 | November 2015 | Page 6 


\section{Materials and Methods}

This research work was carried out in Jutpani VDC of Chitwan Nepal from July to December 2012. The study was designed to assess the situation of TB in the study area. A total of 200 TB suspected patients visiting Jutpani PHC with the clinical history of two or more week's continuous cough, fever, and marked weight loss were included for prevalence study. Sputum samples of three consecutive days from total of peoples were collected and smear examined for Acid Fast bacilli (AFB) at the laboratory of Jutpani PHC and diagnosed after staining by Z-N method. A questionnaire survey of 57 smear positive TB patients was done to assess their Knowledge, Attitude and Preventive Practice (KAP) towards TB.

\section{Results}

Out of 200 TB suspected patients, 18(9\%) were found smear positive. Out of 18(9\%) smear positive patients, $10(55.56 \%)$ were male and $8(44.44 \%)$ were female and highest prevalence of smear positivity (38.89\%) was found in the age group of 30-40. Table 1 shows the age and sex wise prevalence of PTB in Jutpani VDC. Out of 18(9\%) smear positive cases, highest prevalence of tuberculosis was found in the ward number four (5/18) of the VDC which constitutes $27.78 \%$, followed by the ward number one (4/18) which constitute $22.22 \%$ (Table 2). Among the 57 pulmonary TB patients interviewed, 46(80.7\%) believed that blood in sputum, 41(71.9\%) believed evening rise in fever, 16(28.1\%) believed weakness and loss of weight and 12(21.1\%) believed continue cough for more than 3 weeks were the symptoms of TB. Similarly, among 57 TB patients of Jutpani VDC, 47(82.5\%) believed that TB is a communicable disease and majority of them, 30(52.6\%) believed that TB can be prevented by avoiding the personal contact with the TB patient and few of them 25(43.9\%) believed that It can be prevented from transmission by providing public awareness about the TB. Out of 57 patients, 41(71.9\%) believed that consuming excessive alcohol is the cause of TB and 40(70.1\%) believed that smoking is the cause TB. Only 10(17.5\%) peoples knew Mycobacterium tuberculosis is the causative organism of TB. Similarly, majority of the respondent $41(71.9 \%)$ agree that TB can be prevented but only 2(3.5\%) strongly disagree. More than half of the respondents $33(57.6 \%)$ agreed to the statement that if one family member is infected, other family members will also develop TB.

Table 1. Age and sex wise prevalence of PTB

\begin{tabular}{|c|c|c|c|c|c|c|c|}
\hline \multirow{2}{*}{$\begin{array}{ll}\text { Age in } \\
\text { years }\end{array}$} & \multicolumn{2}{|c|}{ Male Patients } & \multicolumn{2}{|c|}{ Female patients } & \multirow{2}{*}{$\begin{array}{l}\text { Total slide } \\
\text { number }\end{array}$} & \multirow{2}{*}{$\begin{array}{l}\text { Total } \\
\text { positive } \\
\text { slides }\end{array}$} & \multirow{2}{*}{$\begin{array}{l}\text { Slide } \\
\text { Positivity } \\
\text { Rate (\%) }\end{array}$} \\
\hline & $\begin{array}{l}\text { Total } \\
\text { slide }\end{array}$ & $\begin{array}{l}\text { Positive } \\
\text { slides }\end{array}$ & $\begin{array}{l}\text { Total } \\
\text { slide }\end{array}$ & $\begin{array}{l}\text { Positive } \\
\text { slides }\end{array}$ & & & \\
\hline$<10$ & 4 & 0 & 2 & 0 & 6 & 0 & $\mathbf{0}$ \\
\hline $10-20$ & 17 & 2 & 17 & 0 & 34 & 2 & 5.89 \\
\hline $20-30$ & 13 & 1 & 27 & 3 & 40 & 4 & 10.00 \\
\hline $30-40$ & 13 & 3 & 23 & 4 & 36 & 7 & 19.44 \\
\hline $40-50$ & 12 & 1 & 13 & 0 & 25 & 1 & 4.00 \\
\hline $50-60$ & 20 & 1 & 14 & 1 & 34 & 2 & 5.89 \\
\hline $60-70$ & 9 & 1 & 6 & 0 & 15 & 1 & 6.67 \\
\hline $70-80$ & 4 & 0 & 2 & 0 & 6 & 0 & $\mathbf{0}$ \\
\hline $80-90$ & 4 & 1 & 0 & 0 & 4 & 1 & 25 \\
\hline Total & 96 & 10 & 104 & 8 & 200 & 18 & $9 \%$ \\
\hline
\end{tabular}

Nepalese Journal of Zoology | Online Volume 3 Issue 1 | November 2015 | Page 7 
Table 2. Ward and Sex wise prevalence of total TB positive patients

\begin{tabular}{|c|c|c|c|c|c|c|c|}
\hline \multirow{2}{*}{$\begin{array}{l}\text { Ward } \\
\text { No. }\end{array}$} & \multicolumn{2}{|c|}{ Male Patients } & \multicolumn{2}{|c|}{ Female patients } & \multirow{2}{*}{$\begin{array}{l}\text { Total slide } \\
\text { number }\end{array}$} & \multirow{2}{*}{$\begin{array}{l}\text { Total } \\
\text { positive } \\
\text { slides }\end{array}$} & \multirow{2}{*}{$\begin{array}{l}\text { Slide } \\
\text { positivity } \\
\text { Rate (\%) }\end{array}$} \\
\hline & $\begin{array}{l}\text { Total } \\
\text { slide }\end{array}$ & $\begin{array}{l}\text { Positive } \\
\text { slides }\end{array}$ & $\begin{array}{l}\text { Total } \\
\text { slide }\end{array}$ & $\begin{array}{l}\text { Positive } \\
\text { slides }\end{array}$ & & & \\
\hline One & 17 & 2 & 24 & 2 & 41 & 4 & 9.75 \\
\hline Two & 6 & 0 & 6 & 0 & 12 & 0 & 0.00 \\
\hline Three & 8 & 1 & 4 & 0 & 12 & 1 & 8.33 \\
\hline Four & 28 & 3 & 34 & 2 & 62 & 5 & 8.06 \\
\hline Five & 4 & 1 & 7 & 1 & 11 & 2 & 18.18 \\
\hline Six & 1 & 0 & 4 & 1 & 5 & 1 & 20.00 \\
\hline Seven & 2 & 0 & 4 & 1 & 6 & 1 & 16.67 \\
\hline Eight & 19 & 2 & 14 & 1 & 33 & 3 & 9.09 \\
\hline Nine & 11 & 1 & 7 & 0 & 18 & 1 & 5.55 \\
\hline Total & & 10 & & 8 & 200 & 18 & $9 \%$ \\
\hline
\end{tabular}

Discussion and Conclusion

Out of 200 TB suspected patients visiting the Jutpani PHC, 18(9\%) samples were found to be positive for acid fast bacilli (AFB). Age wise observation of the smear positivity showed that the highest prevalence of TB 38.89\% (7/18) was found to be in the age group of 30-40. A similar study conducted by Dhungana 2002 at United Mission Hospital Tansen (UMHT) and Dhungana 2004 in TUTH had found the highest prevalence of TB among age group of 20-30 years. The highest prevalence of TB among this age group might be due to the exposure of young people to different environment during their work and activities that will make their health more prone to infection by TB organisms. Highest prevalence of TB in the age group 30-40 is because people of this age group are exposed to the outer environment as well as due to high work load and wide range of mobility. So people of this age group are more prone to the infection with TB organisms.

Sex wise prevalence of TB showed that out of 18 smear positive cases, 10(55.54\%) male and 8(44.46\%) female. Similar higher prevalence of tuberculosis in males compared to females has been reported by other earlier studies carried out in Gorkha district (Smith et al. 1994), in histo-pathological studies at TUTH (Shrestha 1989). Present study revealed high prevalence of TB in the month of Asar 33.33\% (6/18) followed by Shrawan and Bhadra which had the similar prevalence of $22.22 \%$ (4/18). The reason of high prevalence of TB in Asar might be due to high incidence of cough and cold which may help in the transmission of PTB during coughing in the month due to seasonal change. Moreover a study done in Chitwan by Dhital (2007) in CMCTH found that Asar, Shrawan and Bhadra had more incidence of upper respiratory tract infection than other months of the year which support the finding of the present study. Present study revealed that the highest prevalence of TB among illiterate people (28.1\%). Similarly highest prevalence of PTB was found among farmers (49.1\%) followed by people in service $(22.80 \%)$ in relation to the occupation. This showed that occupation of the individuals also plays a major role in the prevalence of TB. Lifson et al. (1999) stated that the risk of TB is greater in areas of residence characterized by crowding, poverty and lower education. In another study, National Tuberculosis Center

Nepalese Journal of Zoology | Online Volume 3 Issue 1 | November 2015 | Page 8 
also found that majorities of the respondents $(67.8 \%)$ were employed in the agriculture sector - as farmers (NTC 2009). Among the 57 TB patients interviewed, majority of them, 30(52.6\%) believed that TB can be prevented by avoiding the personal contact with the TB patients. About $40 \%$ of the respondents in Sindhupalchowk, one of the hilly district believed that the infection could be prevented by covering mouth and nose while coughing and sneezing (NTC 2009). But present study showed that only 7(12.3\%) believe on personal protection like using mask could prevent TB transmission. It showed that the knowledge about TB prevention is poor among the TB patients of this VDC as compared to the people of Sidhupalchowk district.

Similarly, 41(71.9\%) believed that consuming excessive alcohol was the cause of TB and 40(70.1\%) believed that smoking was the cause TB. Only 10(17.5\%) peoples knew Mycobacterium tuberculosis is the causative organism of TB in this VDC. Similar study conducted in Rajasthan showed only 1.6\% had knowledge of tuberculosis causative agent (Yadav et al. 2006) which is very less than the present study where $26.3 \%$ have the knowledge about the causative organism of TB as Mycobacterium tuberculosis. Present study reveled that $94.7 \%$ (54) patients under DOTS said that they had general knowledge about TB. But study carried out in Gorkha as reported earlier, 88\% (Sharma 2008) and in Patan Hospital 75.86\% (Joshi 2004) indicated impressive knowledge of TB as maximum participants knew TB as the infectious diseases. This showed that people in Chitwan have comparatively poor knowledge about the infectious nature of TB. This may be one of the main reasons of high prevalence of TB among the study population.

\section{References}

Dhital, M. 2007. Incidence of Respiratory tract infection among the patients visiting CMCTH, Chitwan, Nepal. Clinical Infectious Diseases 47: 765-8.

Dhungana, G.P. 2004. Tuberculosis and HIV co-infection in Kathmandu valley. M.Sc. Thesis. Central Department of Microbiology, Tribhuvan University, Kathmandu, Nepal.

Dhungana, J.R. 2002. Tuberculosis and HIV co-infection in patients attending Tansen Hospital Palpa. M.Sc. Thesis. Central Department of Microbiology, Tribhuvan University, Kathmandu, Nepal.

DoHS. 2004/2005. Annual Report, Ministry of Health and Population, Department of Health Services, Kathmandu, Nepal.

Grange, J.M., Greenwood, D., Slack, R.C. and Peuthere, J.F. 1998. Medical Microbiology $15^{\text {th }}$ ed. ELBS Churchill Livingstone, UK, 215 p.

Joshi, R.S. 2004. Prevalence of Pulmonary Tuberculosis in relation to socio-behavioral aspects in patients visiting in patan hospital. M.Sc. Thesis. Central Department of Zoology, Tribhuvan University, Kathmandu, Nepal.

Kumar, V., Abbas, A.K., Fausto, N. and Mitchell, R.N. 2007. Robbins Basic Pathology $8^{\text {th }}$ ed. Saunders Elsevier $522 \mathrm{p}$.

Lifson, A.R., Halcon, L.L., Miller, C.A. 1999. Tuberculin skin testing among economically disadvantage dough in a federally funded job training program. American journal of epidemiology 149: 667-678

Shrestha, H.G. 1989. Extra-pulmonary tuberculosis in Nepal. Journal of the Nepal Medical Association 9: $16-23$

Miller, B. and Schieffelbein, C. 1998. Tuberculosis, Bulletin. WHO 76: 141-143.

Nepalese Journal of Zoology | Online Volume 3 Issue 1 | November 2015 | Page 9 
NTC. 2009. Knowledge, Attitude and Practices Study on Tuberculosis among community People, Report of Sindhupalchowk District, National Tuberculosis Center, Kathmandu, Nepal.

Sharma, S.K. 2008. A study on prevalence of Pulmonary Tuberculosis among the suspected cases visiting in Gorkha District hospital, Nepal and TB awareness among them. M.Sc. Thesis. Central Department of Zoology, Tribhuvan University, Kathmandu, Nepal.

Smith, I. 1994. Prevalence of Tuberculosis in Gorkha district, Nepal. Journal of the Nepal Medical Association TB special 18: 14-19.

WHO. 2012a. Tuberculosis Control in the South-East Asia Region, World Health Organization, Geneva, Switzerland.

WHO. 2012b. Global tuberculosis report 2012, World Health Organization, Geneva, Switzerland.

Yadav, S.P., Mathur, M. L. and Dixit, A. K. 2006. Knowledge and attitude towards TB among sandstone quarry worker in desert parts of Rajasthan. Indian J Tuberc 53: 187-195.

Nepalese Journal of Zoology | Online Volume 3 Issue 1 | November 2015 | Page 10 